九州大学学術情報リポジトリ

Kyushu University Institutional Repository

RECORDS OF THE STREPSIPTERA FROM AUSTRALIA AND SRI LANKA IN THE COLLECTION OF THE SMITHSONIAN INSTITUTION, WITH DESCRIPTIONS OF FOUR NEW SPECIES (Notulae Strepsipterologicae-XI)

Kifune, Teiji

Hirashima, Yoshihiro

https://doi.org/10.5109/2444

出版情報: ESAKIA. 20, pp.157-165，1983-12-15. Entomological Laboratory， Faculty of Agriculture, Kyushu University

バージョン :

権利関係 : 


\title{
RECORDS OF THE STREPSIPTERA FROM AUSTRALIA AND SRI \\ LANKA IN THE COLLECTION OF THE SMITHSONIAN \\ INSTITUTION, WITH DESCRIPTIONS OF FOUR NEW SPECIES (Notulae Strepsipterologicae-XI)*
}

\author{
T EIJI KIFUNE \\ Department of Parasitology, School of Medicine, \\ Fukuoka University, Fukuoka 814-01, Japan \\ and \\ YoshIHIRO HIR A S H IM A \\ Entomological Laboratory, Faculty of Agriculture, \\ Kyushu University, Fukuoka 812, Japan
}

\begin{abstract}
Based on the male material kept at the Smithsonian Institution, U. S. A., four new species of the Strepsiptera, Mengenilla australiensis from Australia, Triozocera ceylonensis, Halictophagus radialis, and H. minimus from Sri Lanka, are described. Tridactylophagus ceylonensis and Stichotrema acutipenis are also recorded from Sri Lanka.
\end{abstract}

By the courtesy of Dr. Karl V. Krombein, the Smithsonian Institution, Washington, D. C., U. S. A., we could again examine 9 male strepsipterans collected at light in Australia and Sri Lanka. The result of their taxonomical studies is given in this paper. As a result of the present study, 15 species of the Strepsiptera are known to occur in Sri Lanka.

All materials, including the holotypes of new species, are deposited in the Department of Entomology, Smithsonian Institution, Washington, D. C., U. S. A.

We are very grateful to Dr. Karl V. Krombein of the Smithsonian Institution for the loan of the present material.

\section{MENGENILLIDAE}

\section{Mengenilla australiensis, new species}

Male (Figs. 1-5)

* Contribution from the Entomological Laboratory, Faculty of Agriculture, Kyushu University, Fukuoka (Ser. 3, No. 139). 
Size. Total length of body $3.10-3.14 \mathrm{~mm}$; length of head and thorax together 1.88-2.02 mm; head breadth $0.72-0.74 \mathrm{~mm}$; metathoracic breadth 0.74 $0.76 \mathrm{~mm}$; length of aedeagus $0.29-0.30 \mathrm{~mm}$.

Color. Generally light brown ; head and thorax brown; eyes dark brown; hind wing slightly brownish.

Structure. Typical form of the genus. Head trapezoidal, basements of antennae slightly protruded; eyes oval, each eye composed of about 60 facets and about 30 of them visible from above; antennae 6-segmented, 1st and 2nd segments disc-like, 3rd to 5th segments each with long flabellum, flabellum of 3rd segment slightly shorter than others; Hofeneder's organ remarkable near the underside of the basal portion of 4th segment; mandibles curved inwardly; maxillary palpi 2-segmented, distal segment as long as proximal.

Anterior margin of pronotum slightly evolved, broader than posterior margin ; mesonotum slightly broader than pronotum, posterior margin roundly
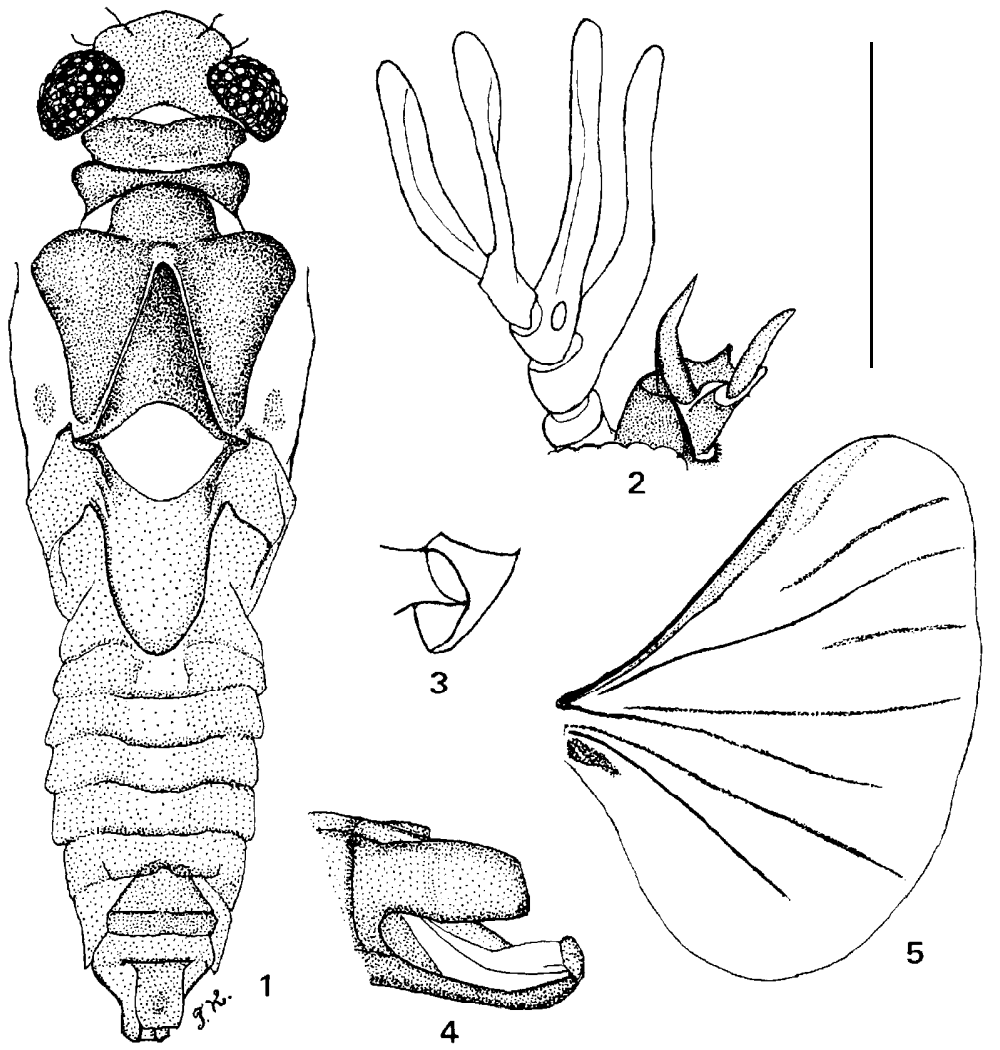

Figs. 1-5. Mengenilla australiensis, new species. 1: Body, dorsal view. 2: Right antenna and mouth parts, ventral view. 3: Right hind coxa, ventral view. 4: Genital capsule, left lateral view. 5: Right hind wing, dorsal view. Scale: $1 \mathrm{~mm}$ for 1 and 2, $0.5 \mathrm{~mm}$ for 3 and $4,2 \mathrm{~mm}$ for 5 . 
emarginated ; prescutum roundly protruded, posteriorly fused with scuti; anterior margins of scuti slightly rounded; scutellum one and a quarter times as long as broad, of isosceles triangle in form, posterior margin remarkably concave ; postlumbium rhomboid, both anterior and posterior margins remarkably curved ; postscutellum almost as long as scutellum by the median lengths, about one and a half times as long as broad at base. Legs normal, tarsi 5-segmented with 2 claws. Hind wing as shown in Fig. 5; veins not so strongly sclerotized.

Abdomen elliptical ; tergit es not strongly sclerotized ; 8th tergite trapezoidal, rather well sclerotized; genital capsule pentagonal ; 10th tergite oblong; aedeagus cylindrical in basal half and triangular in apical half.

Female and triungulin. Unknown.

Host. Unknown.

Type material: Holotype male, $8 \mathrm{~km} \mathrm{~N}$ of Kulgera, N. T., Australia, at black light, 3. Apr. 1980, G. F. Hevel \& J. A. Fortin leg.; paratype male (the smaller specimen), same data as the holotype. Both are preserved in alcohol.

Remarks: The present new species falls to M.kaszabi from Mongolia by the key proposed by us (1980), but differs from it by broader distance between eyes and roundly protruded anterior margins of scuti. According to Riek (1970), 8 species of this genus are known to occur in Australia, but only one of them, M.gracilipes, has been named until today. The present new species is easily distinguishable from $M$.gracilipes in having more facets in the type and other morphological characters.

\section{CORIOXENIDAE}

\section{TRIOZOCERINAE}

\section{Triozocera ceylonensis, new species}

Three specimens collected at different localities were examined. One specimen is well sclerotized but its abdomen is extremely bent dorsally. Other two are rather juvenile and their hind wings destroyed but not deformed. Except the hind wing, all illustrations are made on one of these specimens. Measurement was also performed on it.

Male (Figs. 6-9)

Size (a paratype). Total length of body $3.9 \mathrm{~mm}$; length of head and thorax together $2.5 \mathrm{~mm}$; head breadth $1.06 \mathrm{~mm}$; length of aedeagus $0.90 \mathrm{~mm}$.

Color. Generally reddish brown in well sclerotized specimen. Eyes black; postlumbium and other less sclerotized portion brown; hind wings fuscous.

Structure. Typical form of the genus. Head elliptical, broader than long; eyes hemispherical, each composed of about 18 to 19 facets and about 13 of 


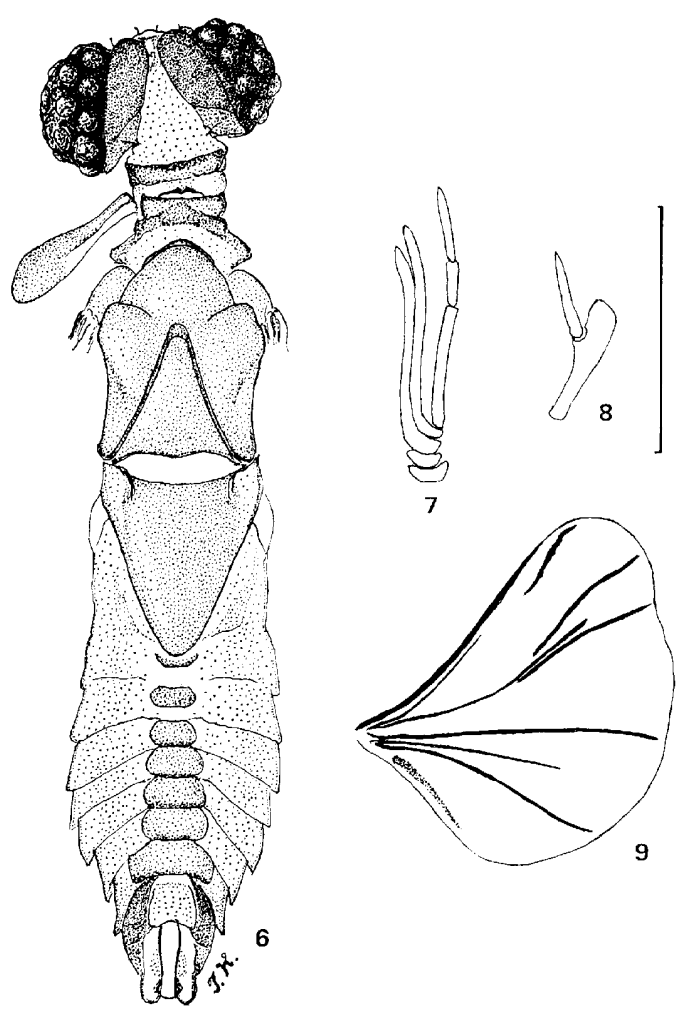

Figs. 6-9. Triozocera ceylonensis, new species. 6: Body, dorsal view. 7: Right antenna, dorsal view. 8: Left maxillary palpus, lateral view. 9: Right hind wing, dorsal view. Scale: $1 \mathrm{~mm}$ for 6 and $7,0.5 \mathrm{~mm}$ for $8,2 \mathrm{~mm}$ for 9 .

them visible from above; antennae 7-segmented, 1st and 2nd segments short, disc-like, 3rd and 4th segments each with long flabellum, 5th longest, slightly shorter than 6 th and 7 th combined together, 7 th clearly longer than 6th; flabellum of 3rd segment reaching the basal third of 7 th and that of 4 th the apical third of 7th; maxillary palpi Z-segmented, distal segment lanceolate, its distal half surpassing tip of proximal segment.

Prothorax about two-fifths as broad as head; anterior margin of mesonoturn as broad as pronotum ; metathorax almost as broad as head but scuti clearly narrower than head, prescutum roundly protruded, posteriorly fused with scuti; scutellum almost as long as broad at base, triangular; postlumbium transverse ; postscutellum conical, slightly longer than scuti at median portion. Legs normal, each with 2 claws. Hind wing as shown in Fig. 9; radius short, detached vein of radius remarkable, situated near the anterolateral angle of wing; jugal vein conspicuous, elongated triangular.

Abdomen strongly bent dorsally in well sclerotized specimen, but generally spindle-formed in not sclerotized one (Fig. 6) ; tergites 2-8 more or less 
sclerotized. Second to 7th tergites transversely elliptical, 8th trapezoidal; genital capsule elliptical, 10th tergite oblong, posterior margin medianly emarginated; aedeagus lanceolate, its apical third tapering, not constricted.

Female and triungulin. Unknown.

Host. Unknown.

Type material : Holotype male, Hunuwilagama near Wilpattu, $200 \mathrm{ft}$, Ann. Dist., Sri Lanka, at black light, 28. Oct.-3. Nov. 1976, G. F. Hevel, R. E. Dietz IV, S. Karunaratne \& W. Balasooriya leg.; 2 paratype males, Chundikkulam, 25 ft., Jaf. Dist., Sri Lanka, at black light, 7. Nov. 1976, G. F. Hevel, R. E. Dietz IV, S. Karunaratne \& D. W. Balasooriya leg., and Mau Ara, 100 m., 10 miles E of Udawalawa, Mon. Dist., Sri Lanka, at black light, 24-26. Sept. 1977, K. V. Krombein, P. B. Karunaratne, T. Wijesinhe \& M. Jayaweera leg. All are preserved in alcohol.

REMARKS: The present new species runs to T.tecpanensis from Mexico in the key presented by us (1979), but differs from it by larger size of body, long maxillary palpi, broader postscutellum, and short jugal vein of hind wing. Chaudhuri \& Das Gupta (1979) described T.pugiopennis (sic!)* from West Bengal, India. We (1979) also described $T$. siamensis from Thailand. The present new species, however, differs from the former by the longer flabella of the 3rd and 4th antenna1 segments and from the latter by the longer distal segment of maxillary palpi and slightly longer scutellum and postscutellum.

\section{MYRMECOLACIDAE}

Stichotrema acutipenis (Kogan et Oliveira, 1964)

Caenocholax (Rhipidocolax) acutipenis. Studia en t., 7: 467, figs. 4-51. (N ew Guinea)

The present material, only 1 male, is identical to this species in spite of the geographical remoteness.

Specimen examined :1 male, Talawila, $100 \mathrm{ft}$., Wilpattu Park, Put. Dist ,, Sri Lanka, at black light, 9-10. Apr. 1973, Baumann \& Cross leg., preserved in alcohol.

Remarks: Though two different spellings, acutipennis in the heading and acutipenis in the explanation and discussion, were used in the original description, we (1980) adopt the latter as the correct name referring the original meaning, sharply pointed aedeagus, according to the Article 32(b) of the International Code of Zoological Nomenclature.

\footnotetext{
* According to the description, this specific name should be spelled as pugiopenis.
} 


\section{HALICTOPHAGIDAE}

\section{Tridacty LOPHAginae}

Tridactylophagus ceylonensis Kifune et Hirashima, 1980

\section{Esakia (15) : 156, fig. 7. (Sri Lanka)}

The present material bears same collecting data as the holotype. This specimen is slightly larger than the holotype as follows: length of head and thorax together $1.6 \mathrm{~mm}$, head breadth $0.70 \mathrm{~mm}$, and metathoracic breadth $0.64 \mathrm{~mm}$. The morphological characters, however, are identical to the holotype of this species.

Specimen examined : 1 male, Hunuwilagama, near Wilpattu, $200 \mathrm{ft}$., Ann. Dist., Sri Lanka, at black light, 28. Oct.-3. Nov. 1976, G. F. Hevel, R. E. Dietz IV, S. Karunaratne, \& W. Balasooriya leg., preserved in alcohol.

\section{H A L I C T O PHAGINAE}

\section{Halictophagus radialis, new species}

Male (Figs. 10-15)

Size. Length of head and thorax together $1.87 \mathrm{~mm}$; head breadth 0.78 $\mathrm{mm}$; length of aedeagus about $0.20 \mathrm{~mm}$.

Color. Generally brown; head and thorax darker, eyes black.

Structure. Head transverse, arch-formed ; eyes flat hemispherical, each composed of about 30 facets; antennae 7-segmented, 1st and 2nd segments short, 3rd to 6th segments short but with flat, long flabellum, 7th segment as long as the flabella of the preceding segments; these flabella radially expanded by fixation; mandibles triangular, very short; maxillary palpi also short, 2-segmented, both segments tubercle-like.

Pronotum triangular, anterior margin roundly curved ; mesonotum medianly very short, but nearly as long as pronotum at the lateral margins, posterior margin evolved so as to receive the following prescutum; prescutum rhomboid, anterior margin roundly convex, separated by suture from scuti; scuti obliquely oblong, anterior margins rounded ; scutellum pentagonal with blunt angles ; postlumbium transverse, shortest at median portion ; postscutellum half as long as metathorax, with almost parallel lateral margins, posterior portion roundly terminated. First tarsal segments of fore legs flattened and expanded; 2nd and 3rd tarsal segments normal. Hind wing with typical venation of the genus. Abdominal segments each well constricted ; ventral side medianly protruded; genital capsule elliptical; 10th tergite ovate, dorsal median line grooved; aedeagus as shown in Fig. 15, with remarkable ventral projection and curved stem.

Female and triungulin. Unknown.

Host. Unknown. 


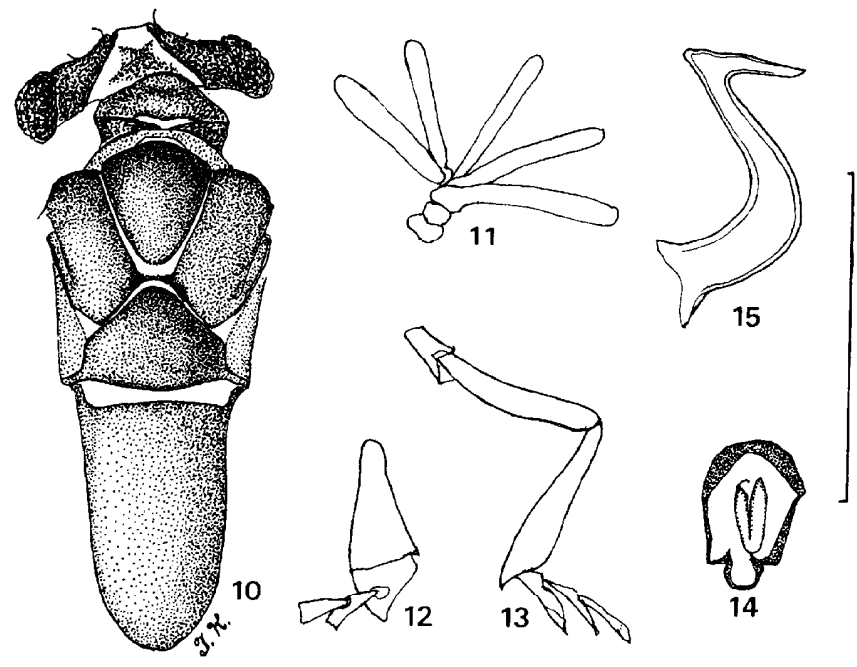

Figs. 10-15. Halictophagus radialis, new species. 10: Head and thorax, dorsal view. 11: Left antenna, frontal view. 12: Right fore tibia and tarsi, ventral view. 13: Left hind leg, ventral view. 14: Genital capsule, dorsal view. 15: Aedeagus, left lateral view. Scale : $1 \mathrm{~mm}$ for $10-14,0.25 \mathrm{~mm}$ for 15 .

Type material : Holotype male, Kitulgala Resthouse, Keg. Dist., Sri Lanka, at black light, 3-5. Feb. 1979, K. V. Krombein, P. B. Karunaratne, T. Wijesinhe, S. Siriwardane \& T. Gunawardane leg., preserved in alcohol. Aedeagus is separately mounted.

REMARKS: The present new species is easily distinguishable from other congeneric species by its characteristic shape of aedeagus. This type of aedeagus shows a certain affinity to the related genus Coriophagus which is usually discriminated by large body size (more than $3 \mathrm{~mm}$ ) and host preference (Coreidae, Heteroptera). The present new species, however, is not so large and other morphological characters do not suggest that this may belong to Coriophagus .

\section{Halictophagus minimus, new species}

Only 1 male specimen obtained together with the preceding new species is available. General morphology is very affinitive to the preceding but easily distinguished by the smaller size. Unfortunately, the head and prothorax were separated from the remaining part of the body and the genital capsule is tightly rolled up. Aedeagus was, therefore, not observed without destroying the capsule.

Male (Figs. 16-20)

Size. Estimated length of head and thorax combined together about 1.32 

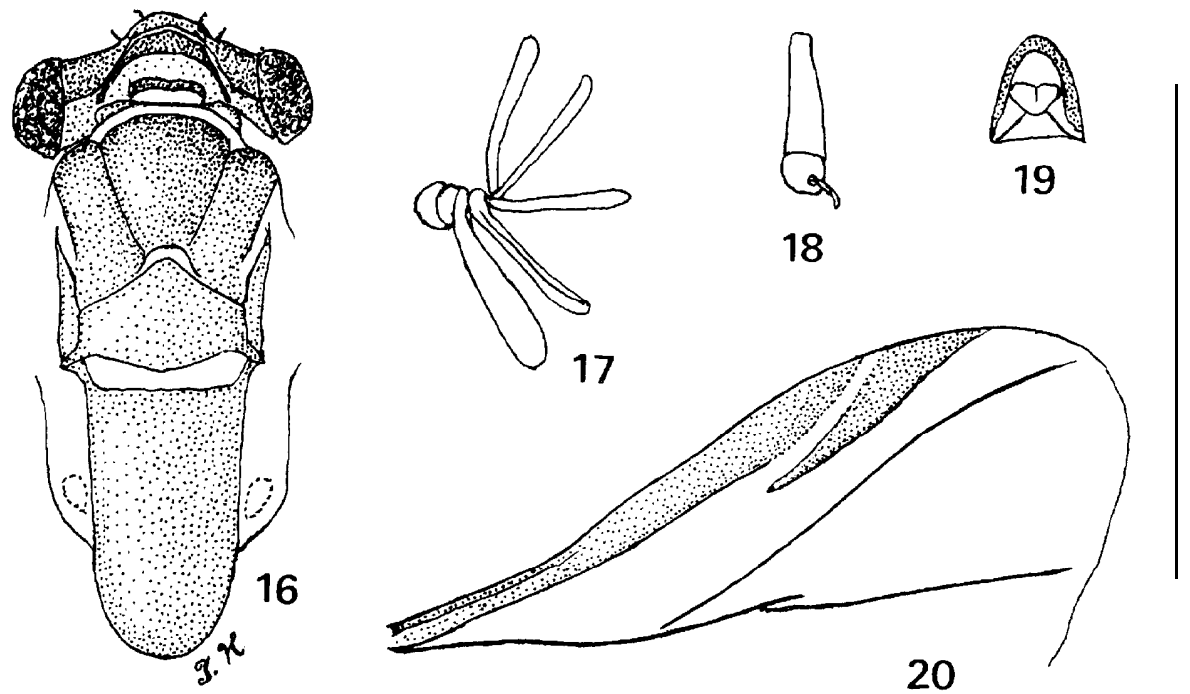

Figs. 16-20. Halictophagus minimus, new species. 16: Head and thorax, dorsal view. 17: Left antenna, frontal view. 18: Left fore tibia and tarsi, lateral view. 19: Genital capsule, dorsal view. 20: Anterior portion of right hind wing, dorsal view. Scale: $1 \mathrm{~mm}$.

$\mathrm{mm}$; head breadth $0.58 \mathrm{~mm}$; metathoracic length $1.12 \mathrm{~mm}$; radial length of hind wing $1.62 \mathrm{~mm}$.

Color. Generally brown ; sclerotized portions darker; eyes black.

Structure. General structure very similar to the preceding species. Head transverse, arch-formed ; eyes hemispherical, each composed of c. 30 facets; antennae almost as in the preceding species; mandibles comparatively large, triangular ; maxillary palpi2-segmented, short, tubercle-like.

Pronoturn very short, belt-like; prescutum comparatively broad against scuti. Genital capsule rather pentagonal, its posterior margin tightly rolled upward so that aedeagus could not be observed. Hind wing of typical venation of the genus; detached vein from radius triangular as shown in Fig. 20. First tarsal segments of fore legs flattened, disc-like.

Female and tirungulin. Unknown.

нозт. Unknown.

Type materias : Holotype male, Kitulgala Resthouse, Keg. Dist., Sri Lanka, at black light, 3-5. Feb. 1979, K. V. Krombein, P. B. Karunaratne, T. Wijesinhe, S. Siriwardane \& T. Gunawardane leg., preserved in alcohol.

Remarks: As shown by the data, this new species was collected at the same time as the preceding new species. The size is similar to H.peradeniya from Sri Lanka, but this is easily distinguished by the shapes of genital capsule and of the antenna.

Three species of Halictophagus have been known from Sri Lanka as enumerated in our previous paper (1980). None of them is, however, identical 
with the two new species described above.

\section{References}

Bohart, R. M. 1962. A new strepsipteran parasitic on Coreidae (Strepsiptera: Halictophagidae and Hemiptera: Coreidae). Proc. ent. Soc. Wash., 64: 91-94.

Brailovsky A. H. \& C. Márquez M. 1974. Una nueva especie mexicana de Triozocera Pirece (Strepsiptera, Mengeidae). An. Inst. Biol., Univ. Nac.autón. Men-., 45(ser. Zool): 105-110.

Chaudhuri, P. K. \& S. K. Das Gupta. 1979. New species of Halictophagus and Triozocera [Strepsiptera from West Bengal, India]. Oriental Ins., 13 : 133-138.

Kifune, T. \& Y. Hirashima. 1979. Two new species of Strepsiptera from Thailand (Notulae Strepsipterologicae-V). Esakia, (14) : 61-71.

- \& - 1980. Records of the Strepsiptera of Sri Lanka in the collection of the Smithsonian Institution, with descriptions of seven new species (Notulae Strepsipterologicae-VI). Ibid., (15): 143-159.

Kinzelbach, R. K. 1970. Die mannlichen Imagines der Mengenillidae und Mengenilla kaszabi n. sp. Ergebnisse der zoologischen Forschungen von Dr. Z. Kaszab in der Mongolei (Strepsiptera, Insecta). R eichenbachia, 12:217-247.

Kogan, M. 1958. A new species of the genus Triozocera Pierce from Brazil (Mengeidae, Strepsiptera). Studia ent., 1: 421-426.

— \& S. J. Oliveira 1964. New Guinean Mengeidae and Myrmecolacidae (Strepsiptera). Ibid., 7 : 459-470.

Lea, A. M. 1910. On a new genus of Stylopidae from Australia. Trans. ent. Soc.Lond., [1910]: 514-516, pl. 66.

Luna de Carvalho, E. 1972. Quarta contribuição para o estudo dos Estrepsipteros angolenses (Insecta Strepsiptera). Publ. cult. Co. Diam. Angola, (84) : 109-150.

Riek, E, F. 1970. Strepsiptera. In: The Insects of Australia, pp. 622-635, CSIRO, Canberra, Melbourne Univ. Press. 